WARSZTATY Z GEOGRAFII TURYZMU

ISBN 978-83-7525-925-4 s. $115-134$

http://dx.doi.org/10.18778/7525-925-4.10

Beata KRAKOWIAK

Uniwersytet Łódzki

Ewelina SKRYDALEWICZ

absolwentka UŁ

\title{
„NOC MUZEÓW" JAKO WYDARZENIE KULTURALNE W WYBRANYCH MIASTACH POLSKI
}

\section{Wprowadzenie}

Jedną z najbardziej popularnych obecnie form turystyki jest turystyka kulturowa. Głównym jej motywem jest chęć poznawania i doświadczania tego, co stanowi materialny i niematerialny przejaw ludzkiej działalności, odwiedzanie i poznawanie miejsc oraz obiektów o wartości historycznej, artystycznej i kulturowej, a także uczestnictwo w imprezach o charakterze kulturalnym (KUREK 2007). Celem tej formy podróżowania są m.in. muzea, które przyciągają eksponatami, wystawami, architekturą swoich siedzib i ich otoczeniem, a coraz częściej także różnorodną działalnością której efektem ma być pozyskanie nowego odwiedzającego. W zależności od podejmowanych przez placówki muzealne zabiegów mogą być one zatem traktowane jako walor, atrakcja czy produkt turystyczny i analizowane jako pojedyncze obiekty, grupa obiektów (np. szlak muzeów) oraz jako wspólna funkcjonalnie przestrzeń, w której instytucje te prowadzą swoją działalność (wyspy muzealne, np. Berlin). 
Jedną z form działalności muzealnej jest organizacja wydarzeń kulturalnych o różnej skali i zasięgu, dzięki którym placówki te są rozpoznawalne w regionie, kraju czy świecie. To między innymi dzięki nim muzea starają się być łatwiejsze $\mathrm{w}$ odbiorze, bardziej przyjazne, dostępne i otwarte na świat (KOWALCZYK 2010). Wydarzeniem, łączącym wiele placówek muzealnych jest „Noc Muzeów”, która na stałe wpisała się w kalendarz europejskich, ale też polskich imprez kulturalnych, umożliwiających ciekawe spędzenie wolnego czasu i uatrakcyjniających codzienne zajęcia. Szacuje się, że w 2012 r. w całej Polsce różne placówki kultury przy okazji tego wydarzenia mogło odwiedzić nawet około $1 \mathrm{mln}$ osób (www.Noc-Muzeów.pl). Niestety oprócz tekstów czysto publicystycznych, artykułów o charakterze badawczym tego wydarzenia jest niewiele, a do ciekawszych zaliczyć należy opracowania pt. Noc Muzeów - zjawisko kulturowe i społeczne ostatnich lat (ROKOSZ, GŁOWACKI 2008) oraz Noc Muzeów w opiniach publiczności (SzELĄG 2008). Pierwszy z nich dotyczy ogólnych rozważań na temat wydarzenia w kontekście zjawiska, które z roku na rok staje się bardziej powszechne, drugi zawiera wyniki badań przeprowadzonych z uczestnikami muzealnej nocy w Poznaniu w roku 2006 i 2007.

Prezentowana praca poniekąd łączy obie te publikacje, ponieważ przedmiotem analizy są $\mathrm{w}$ niej szczegółowe wyniki badań przeprowadzonych w Łodzi, a także dostępne dane dla wybranych miast Polski - Krakowa, Poznania, Trójmiasta, Warszawy i Wrocławia. Miasta te, z uwagi na koncentrację w ich obrębie obiektów historycznych i kulturalnych oraz toczące się życie kulturalne, są centrami kultury i jednocześnie głównymi obszarami rozwoju turystyki kulturowej w naszym kraju (KUREK 2007). Istotnym elementem doboru wymienionych miast była także dostępność informacji na temat organizacji „Nocy Muzeów” w tych ośrodkach przy wykorzystaniu strony www.Noc-Muzeów.pl.

Nadrzędnym celem pracy jest pokazanie specyfiki tego wydarzenia oraz tendencji ujawniających się $\mathrm{w}$ ciągu kolejnych lat organizacji imprezy. W poszczególnych częściach artykułu zaprezentowano ideę „Nocy Muzeów", jej organizację w dużych miastach Polski, charakterystykę wydarzenia w Łodzi oraz słabe i mocne strony charakteryzowanej akcji kulturalnej. 


\section{Idea i początki „Nocy Muzeów” w Europie i w Polsce}

Idea „Nocy Muzeów” narodziła się na obszarze Niemiec, gdzie w 1997 r. w Berlinie zorganizowano po raz pierwszy Lange Nacht der Museen (rys. 1). Ze względu na duże zainteresowanie tym wydarzeniem niebawem pojawiło się ono również na terenie Francji (jako „Wiosenny czas muzeów”), a stopniowo także $\mathrm{w}$ innych państwach europejskich (rys. 2). Od 2005 r. wydarzenie to odbywa się pod wspólną nazwą "Europejska Noc Muzeów”, a patronat nad nim sprawuje Rada Europy. W 2003 r. do akcji tej przystąpiła także Polska, w której pierwszym miastem organizującym wydarzenie był Poznań (www.Noc-Muzeów.pl).

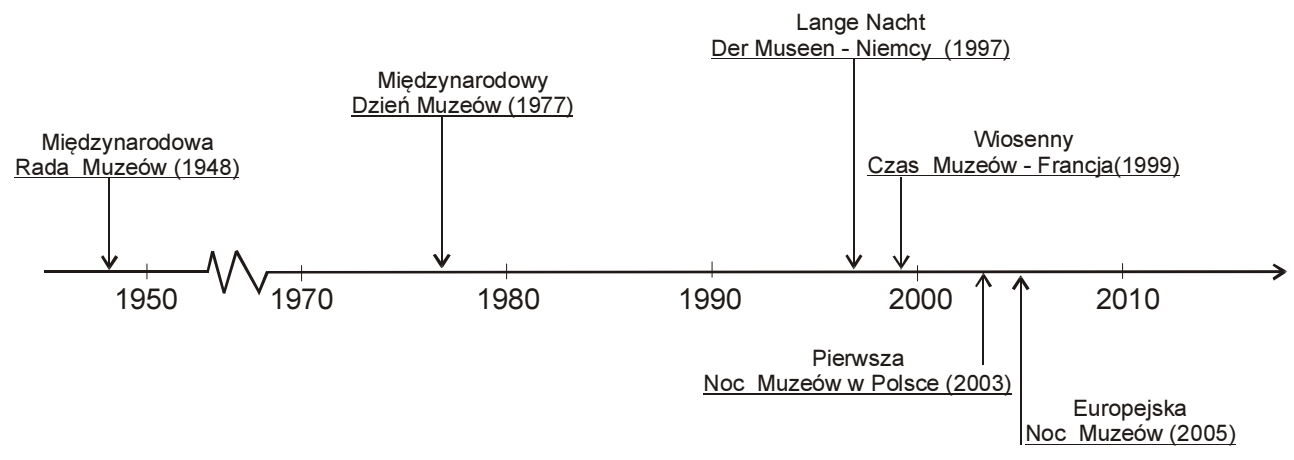

Rys. 1. Najważniejsze wydarzenia związane z „Nocą Muzeów”

Źródło: opracowanie własne
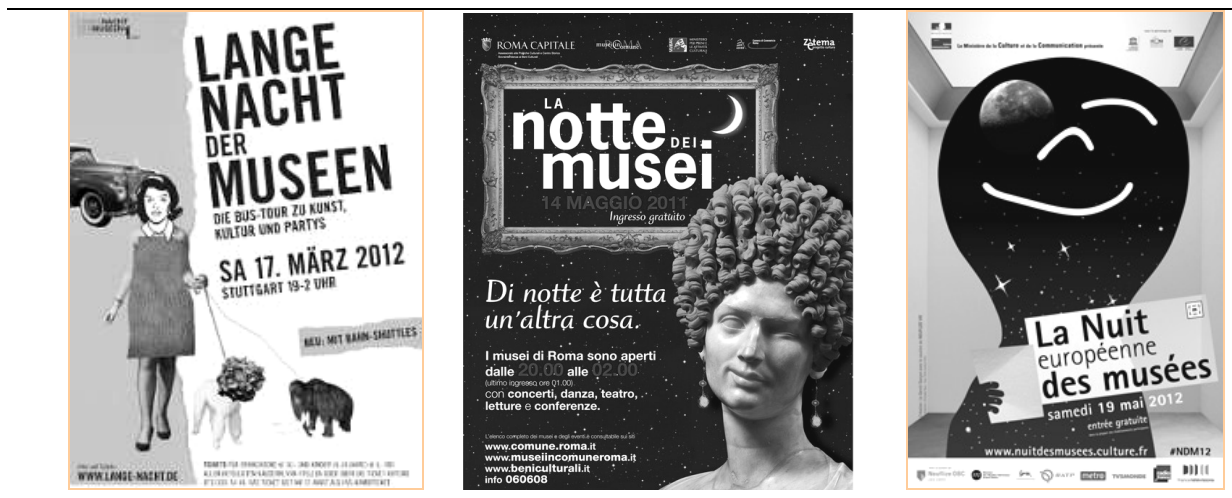

Rys. 2. Plakaty reklamujące „Noc Muzeów” na terenie Niemiec, Włoch i Francji

Źródło: www.konrad-auwaerte r.de, www. daringtodo.com, www. Nuitdesmusees.culture.fr 
Głównym celem wydarzenia jest popularyzacja i promocja zbiorów muzealnych poprzez darmowe (lub za symboliczną opłatę) ich udostępnianie poza tradycyjnymi godzinami otwarcia. Dodatkowo akcja ma spowodować nawyk praktykowania kultury oraz przyciągnąć młodych widzów do instytucji działających w sferze kultury.

„Noc Muzeów" nie jest jedynym wydarzeniem kulturalnym, które odbywa się nocą. W ramy szeroko rozumianej działalności kulturalnej wpisują się także np. „Noc Kultury” w Lublinie, „Noc Kulturalna” organizowana w Częstochowie, "Krakowskie Noce” (obejmujące organizowane w różnych terminach noce: teatrów, jazzu, muzeów i noc sakralną) czy bardziej wyspecjalizowane i organizowane w wielu miejscach kraju "Noc Teatrów” czy „Noc Kin”. W formułę wydarzenia wpisuje się także „Noc Naukowców” zainicjowana w 2005 r. przez Komisję Europejska, a organizowana w wielu państwach europejskich przy wsparciu m.in. Unii Europejskiej (rys. 3).
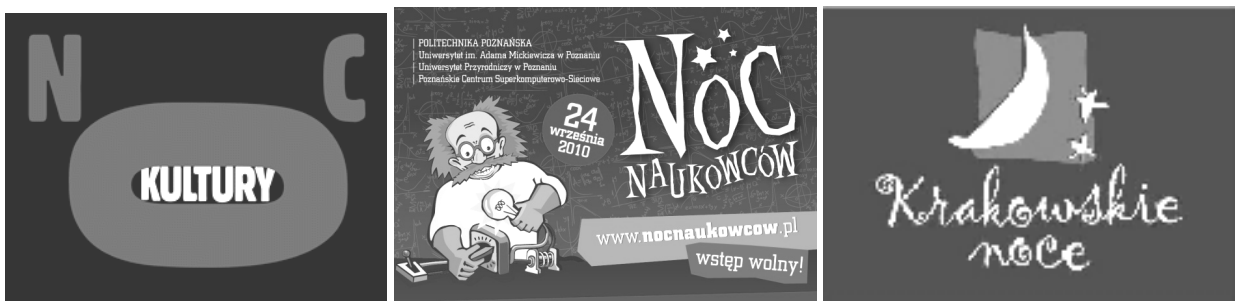

Rys. 3. Logo wybranych wydarzeń kulturalnych odbywających się nocą

Źródło: www.lublin.dlastudenta.pl, www.poznan.planeta.fm, www.szlakimalopolski.mik.krakow.pl

Wymienione jako przykłady imprezy, choć organizowane w różnej skali i przy zaangażowaniu różnych podmiotów łączy pora, w której się one odbywają. Dlaczego noc? Na pewno dlatego, że wtedy potencjalni zainteresowani mają wolny czas, także dlatego, że noc tworzy odpowiednią oprawę i czyni wydarzenie wyjątkowym (tym bardziej, że wiele imprez towarzyszących odbywa się w plenerze). Określenie „noc” ma w tym przypadku oczywiście znaczenie umowne, bo zazwyczaj godziny otwarcia instytucji w czasie "Nocy Muzeów” zawierają się pomiędzy 18.00 a 1.00 (zależy to od obiektu). Ruchomy jest także dzień organizacji tego wydarzenia. Jak dotąd organizowano go w połowie maja, zazwyczaj z soboty na niedzielę, a święto muzeów w 2013 r. ustalone zostało na 18-19 maja. 
„Noc Muzeów" to przede wszystkim impreza kulturalna stworzona z myślą o odwiedzających i dla odwiedzających. Wydarzenie to jest pewnego rodzaju odpowiedzią na ustanowiony przez Międzynarodową Radę Muzeów w 1977 r. Światowy Dzień Muzeów, przypadający na 18 maja i będący świętem muzealników (rys. 1). Na tę specjalną noc w roku instytucje kultury szykują na ogół specjalne atrakcje. Obejmują one m.in. wystawy, prelekcje, koncerty czy pokazy (tab. 1). Wszystkie wymienione formy działalności wpisują się m.in. w zadania muzeów określone w Ustawie o muzeach z 1996 r.

Tabela 1. Grupy atrakcji proponowanych w czasie „Nocy Muzeów” a funkcje muzeów

\begin{tabular}{|l|c|}
\hline \multicolumn{1}{|c|}{ Grupy atrakcji } & Rodzaj działalności \\
\hline Wystawy stałe, czasowe, plenerowe & ekspozycyjna \\
\hline Wykłady, prelekcje, warsztaty & edukacyjna \\
\hline Projekcje, koncerty, spotkania & kulturalna \\
\hline Happeningi, pokazy, inscenizacje & rozrywkowa \\
\hline
\end{tabular}

Źródło: opracowanie własne.

Z perspektywy organizatora przygotowania do „Nocy Muzeów” to czas wzmożonego wysiłku, koncentracji sił, kreatywnego myślenia, a wszystko po to, aby prezentowana oferta była ciekawa, różnorodna, przyciągnęła jak najwięcej odwiedzających i pozwalała pokazać się placówce z jak najlepszej strony.

\section{3. „Noc Muzeów” w dużych polskich miastach}

„Noc Muzeów” w Polsce jawi się jako wybitnie miejskie wydarzenie, co wynika z faktu, że muzea są obiektami turystycznymi charakterystycznymi dla miast, a liczba placówek muzealnych w mieście i ich znaczenie ma związek z jego wielkością i rangą. Wśród miast uprzywilejowaną pozycję zajmują miasta wojewódzkie. Szczególne znaczenie odgrywa tu stolica Polski Warszawa, w której zlokalizowanych jest około 50\% (ok. 70 obiektów) wszystkich muzeów województwa. Wysoki udział muzeów charakteryzuje także dawną stolicę kraju - Kraków oraz stolice regionów - Wrocław, Szczecin i Gdańsk (ok. 1/3 muzeów danego województwa). Prezentowane 
wyniki wskazują że główne miasta w województwach jako centra administracyjne pełnią także funkcję ważnych ośrodków kulturalnych, dystansując pod tym względem pozostałe miejscowości w regionie (KRAKOWIAK 2007).

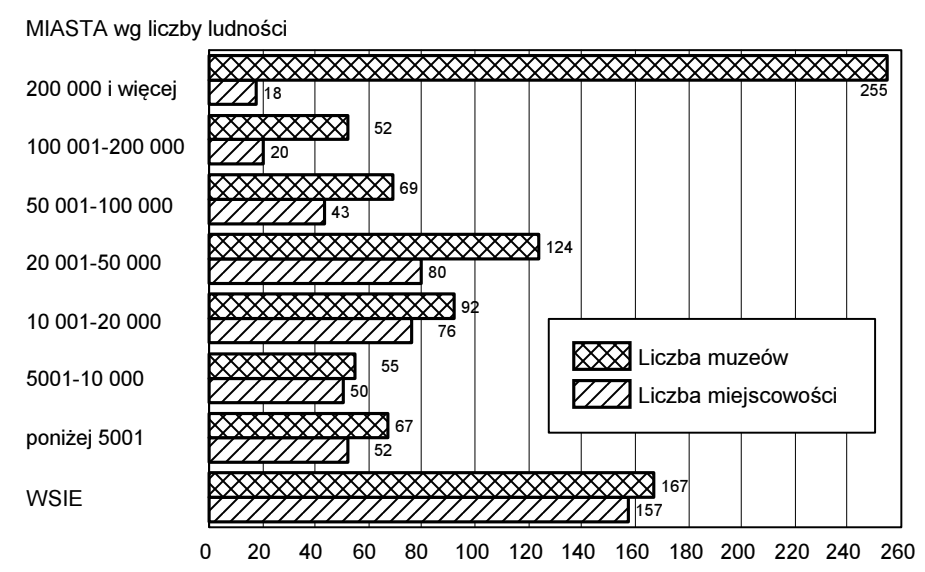

Rys. 4. Liczba muzeów według wielkości miast w Polsce na podstawie danych KOBiDZ, $2007 \mathrm{r}$. Źródło: opracowanie własne

Analiza liczby muzeów w zależności od wielkości miast wskazuje, że placówki muzealne dominują w miastach powyżej 200 tys. mieszkańców oraz $\mathrm{W}$ miastach z przedziału 20-50 tys. mieszkańców (rys. 4). W grupie pierwszej znajdują się przede wszystkim miasta wojewódzkie, a wśród nich Warszawa, Kraków, Poznań, Wrocław czy Gdańsk. W ośrodkach tych występują zróżnicowane co do zbiorów placówki muzealne, w tym muzea narodowe z licznymi oddziałami. Grupę drugą tworzą miasta powiatowe i duże ośrodki gminne. W miejscowościach tych zlokalizowane są muzea regionalne, muzea miejskie, czasami także inne tego typu placówki (KRAKOWIAK 2007).

Według oficjalnej strony Europejskiej Nocy Muzeów, w 2010 r. w wydarzeniu uczestniczyło około 120 miast europejskich reprezentujących różne kraje, w tym 24 polskie miasta (oficjalnie zarejestrowane na stronie, po dopełnieniu wszystkich formalności). Z kolei według różnych źródeł krajowych, w 2010 r. w polskiej „Nocy Muzeów” wzięło udział około 60 miast, a 2012 r. - blisko 100. Prezentowane dane mają jedynie szacunkowy charakter, bowiem nie prowadzi się dokładnego rejestru. Należy jednak sądzić, że wraz z popularyzacją wydarzenia wzrasta zainteresowanie nim miast i róż- 
nych instytucji. Fakt ten potwierdzają tab. 2 i rys. 5 pokazujące uczestnictwo w „Nocy Muzeów” wybranych miast w Polsce. Wynika z nich, że w samej tylko Warszawie w 2012 r. w "Nocy Muzeów” wzięło udział ponad 180 instytucji kultury i nauki, które według danych prasowych odwiedziło około 200 tys. osób (www.Noc-Muzeów.pl). Warszawa jako stolica zdecydowanie zdystansowała pozostałe ośrodki miejskie, pomiędzy którymi pojawiły się też duże dysproporcje pod względem liczby uczestniczących podmiotów. $Z$ dostępnych danych wynika, że kolejne miejsca przypadły Trójmiastu i Krakowowi (po około 60 instytucji), a na dalszych pozycjach znalazły się Wrocław, Łódź i Poznań. Porównanie wartości liczbowych dla 2010 i 2012 r. potwierdza $\mathrm{w}$ przypadku każdego $\mathrm{z}$ analizowanych miast znaczący przyrost liczby uczestniczących w wydarzeniu podmiotów (np. z 25 do 61 instytucji w Krakowie, z 17 do 30 w Poznaniu), co jest dowodem na wzrastające zainteresowanie tą imprezą kulturalną po stronie instytucji.

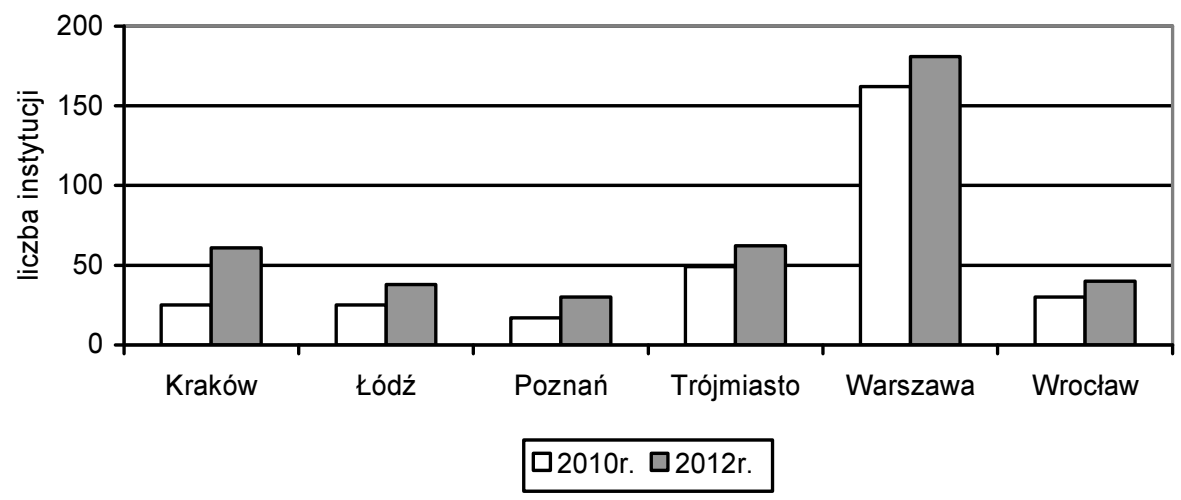

Rys. 5. Liczba instytucji uczestniczących w „Nocy Muzeów” w 2010 i 2012 r. w wybranych miastach Polski

Źródło: opracowanie własne na podstawie www.Noc-Muzeów.pl

Przeglądając szczegółowe programy wydarzenia można wyróżnić kilka kategorii instytucji uczestniczących w muzealnej nocy. Biorąc pod uwagę jego nazwę warto zwrócić uwagę na udział muzeów w ogólnej liczbie podmiotów. W niniejszym opracowaniu do kategorii tej zaliczono muzea i ich oddziały (czasem poza głównym miastem, np. oddziały Muzeum Narodowego w Poznaniu - Gołuchów, Śmiełów, czy Muzeum Narodowego w Gdań- 
sku - Waplewo), a także powstające ostatnio centra nauki (np. Centrum Hewelianum - Gdańsk, Ogród Doświadczeń - Kraków, Centrum Nauki Kopernik - Warszawa), które poprzez prowadzoną działalność o charakterze edukacyjnym zbliżone są do placówek muzealnych. $Z$ dostępnych źródeł wynika, że także pod tym względem omawiane miasta charakteryzują duże dysproporcje, a najbardziej muzealny charakter wydarzenia utrzymuje Kraków (ponad 78\% muzeów w 2012 r.), najmniej zaś Warszawa (ok. 24\%). Tendencja ta jest stała dla dwóch omawianych lat - 2010 r. i 2012 r., choć na przestrzeni tego czasu widać wyraźny spadek udziału muzeów (w niektórych przypadkach nawet o około 17\% - Kraków, Łódź), przy jednocześnie wzrastającej liczbie bezwzględnej tych placówek.

Tabela 2. Udział wielkich miast w Polsce w „Nocy Muzeów” w 2010 r. i 2012 r. z uwzględnieniem placówek muzealnych

\begin{tabular}{|l|c|c|c|c|c|c|}
\hline \multirow{2}{*}{ Miasto } & \multicolumn{3}{|c|}{ Liczba podmiotów w 2010 r. } & \multicolumn{3}{c|}{ Liczba podmiotów w 2012 r. } \\
\cline { 2 - 7 } & ogółem & muzea & $\%$ & Ogółem & Muzea & $\%$ \\
\hline Kraków & 25 & 24 & 96,0 & 61 & 48 & 78,7 \\
\hline Łódź & 24 & 18 & 75,0 & 38 & 22 & 57,9 \\
\hline Poznań & 17 & 12 & 70,6 & 30 & 20 & 66,7 \\
\hline Trójmiasto & 49 & 30 & 61,2 & 62 & 35 & 56,5 \\
\hline Warszawa & 162 & 42 & 25,9 & 181 & 44 & 24,3 \\
\hline Wrocław & 30 & 13 & 43,3 & 40 & 15 & 37,5 \\
\hline
\end{tabular}

Źródło: opracowanie własne na podstawie www.Noc-Muzeów.pl.

Obok muzeów drugą popularną grupę uczestników stanowią galerie i ośrodki kultury - teatry, kina, domy kultury, a także fundacje i stowarzyszenia kulturalne oraz narodowe centra kultury (np. Bułgarski Instytut Kultury - Warszawa, Muzułmańskie Centrum Kulturalno-Oświatowe Wrocław). Ich działalność wydaje się równie wszechstronna jak w przypadku muzeów; najczęściej organizują one wystawy, wernisaże, pokazy, projekcje, i koncerty. Zazwyczaj udział takiej instytucji sprowadza się do organizacji konkretnego projektu, natomiast sama jego realizacja odbywa się przy udziale zaproszonych gości (najczęściej artystów) z zewnątrz. Obserwacje programów kolejnych edycji wydarzenia wskazuja że to właśnie te instytucje $\mathrm{w}$ niektórych miastach zaczynają stopniowo wypierać muzea (Warszawa, Wrocław). 
W „Nocy Muzeów” udział biorą także instytucje naukowe, tj. Polska Akademia Nauk (Warszawa), szkoły wyższe (np. AGH - Kraków, PWSFiT Łódź), biblioteki (np. PAN - Warszawa) czy archiwa oraz instytuty narodowe (Instytuty Pamięci Narodowej - Łódź, Poznań, Wrocław, czy Żydowski Instytut Historyczny - Warszawa). Ciekawostkę stanowi uczestnictwo obiektów i instytucji religijnych, w tym kościołów, parafii i związków wyznaniowych (Kalwaria Wejherowska - Trójmiasto, Żydowska Gmina Wyznaniowa - Warszawa, Parafia Ewangelicko-Reformowana - Łódź). Wymienione kategorie obiektów ze względu na ich ograniczoną liczbę w poszczególnym miastach mają na ogół niewielu przedstawicieli wśród uczestniczących instytucji.

Kolejne edycje pokazuja, że stopniowo zwiększa się nie tylko liczba, ale też różnorodność podmiotów uczestniczących w wydarzeniu. Najbardziej zróżnicowane instytucje biorące udział w "Nocy Muzeów” w badanym okresie charakterystyczne są dla stolicy, w której oprócz muzeów i galerii biorą także udział wszystkie z wymienionych wcześniej kategorii, a dodatkowo także stowarzyszenia i fundacje oraz kawiarnie, kluby itp. Dla wielu $\mathrm{z}$ nich jest to okazja do pokazania się na szerszym forum i zaprezentowania prowadzonej działalności. Ciekawostką w przypadku Warszawy jest udział w wydarzeniu także urzędów i instytucji państwowych. W programie muzealnej nocy udostępniono do zwiedzania m.in. Pałac Prezydencki, Kancelarię Prezesa Rady Ministrów, budynek Sejmu, urzędy wojewódzkie, urzędy miasta wraz z gabinetem Prezydenta Miasta Warszawy. Ogółem obiekty inne niż muzea stanowiły w tym mieście około $75 \%$ wszystkich instytucji-uczestników, co ma oczywiście związek z funkcją stołeczną tego ośrodka.

Przeglądając szczegółowe programy „Nocy Muzeów” przygotowane dla różnych miast w Polsce w 2012 r. zauważyć można ich zróżnicowany charakter, co wiąże się z tym, że są one tworzone niezależnie od siebie, osobno dla każdego z nich, zazwyczaj przy udziale władz miasta. Szczególnie odbiega od innych program dla Warszawy, który przygotowano jednocześnie w polskiej i angielskiej wersji językowej tak, aby mógł być on dostępny dla cudzoziemców. Druga istotna różnica polegała na tym, że szczegółowe propozycje przedstawione zostały w odniesieniu do poszczególnych części miasta (Śródmieście, Bielany, Mokotów). Pod względem merytorycznym warto zwrócić uwagę na to, że ważną postacią tej edycji warszawskiej „Nocy Muzeów" był Bolesław Prus, któremu ze względu na 100. rocznicę śmierci dedykowano specjalne atrakcje przygotowane, m.in. przez muzeum (Muzeum 
Historyczne), przewodników miejskich (Warszawskie Koło Przewodników), biblioteki (Biblioteka Publiczna, Biblioteka Uniwersytecka) czy księgarnie (Główna Księgarnia Naukowa).

Spośród programów warto zwrócić uwagę także na propozycje Poznania. Edycja w 2012 r. przebiegała w nim pod hasłem „Otwarcie muzeum”, co sugerować miało eksponowanie nowych, niepokazywanych dotąd dzieł, obecność nowych widzów oraz otwarcie odwiedzających na muzea. W ramach atrakcji przewidziano np. następujące bloki tematyczne - „Rozmowy przy obiekcie” (obraz, rzeźba, zazwyczaj nie prezentowane na co dzień, w tym wybierane w trakcie głosowania) czy "Muzyka w obiekcie”. W obu przypadkach eksponowano konkretną osobę prowadzącą daną część - kuratora, kustosza, konserwatora, czy zaproszonych artystów, tym samym przygotowana oferta nabierała bardziej personalnego charakteru. Wskazując na odmienności należy odnotować też ofertę Krakowa, który w odróżnieniu od pozostałych miast organizuje "Noc Muzeów” zazwyczaj w innym terminie, tzn. o jeden dzień wcześniej, w nocy z piątku na sobotę.

W każdym $\mathrm{z}$ analizowanych miast na ogół proponowano podobne atrakcje - wystawy, wernisaże, pokazy, prezentacje, warsztaty czy konkursy, ale przygotowane z myślą o różnych odbiorcach - dzieciach, rodzinach i innych grupach (aspekt wielopokoleniowy występował zwłaszcza w Poznaniu i Trójmieście). Wiele atrakcji wiązało się z zastosowaniem nowoczesnych technologii - komputerów, projektorów czy efektów dźwiękowych. Wśród prezentowanych propozycji dużo wiązało się z aktywnym uczestniczeniem odwiedzających, były to np. warsztaty (niektóre $z$ oferty edukacyjnej, inne specjalnie przygotowane na tę okazję) lub gry połączone z zadaniami do wykonania. Chętnym proponowano zabawy o charakterze integracyjnym ogniska (Poznań), śpiewy i tańce (Trójmiasto). W trakcie muzealnej nocy przewidziano także zwiedzanie niektórych części miast z przewodnikiem (np. Poznań - trakt królewsko-cesarski, Łódź - tereny dawnego getta, Trójmiasto - rejsy statkiem). Komunikację pomiędzy poszczególnymi obiektami ułatwiały zabytkowe tramwaje, autobusy i szybka kolej miejska (Trójmiasto). W akcję włączyło się też PKP Intercity proponując specjalne połączenia pomiędzy Trójmiastem, Poznaniem, Warszawą, Wrocławiem i Katowicami. Do obsługi uczestników „Nocy Muzeów” w niektórych przypadkach zaangażowano osoby z zewnątrz instytucji, np. przyjaciół muzeum (Poznań) czy wolontariuszy i animatorów (Trójmiasto). 
Ogólny wniosek wypływający z analizy programów jest taki, że oferta „Nocy Muzeów" ma duży związek z rangą miejscowości i znajdujących się w niej instytucji kultury, w tym placówek muzealnych. Są miasta, w których muzeów jest wiele, co nadaje wydarzeniu właściwego wymiaru. Z punktu widzenia omawianego zagadnienia ważne jest to, że koncentracja tych placówek ma miejsce w obrębie historycznej części miast, co ułatwia odwiedzenie kilku z nich oraz stanowi, że pewna część miasta „żyje” pomimo późnych godzin nocnych. Niewątpliwym atutem akcji jest także uruchomienie specjalnych połączeń $w$ ramach komunikacji miejskiej (autobus, tramwaj) umożliwiając dostęp do nich zarówno stałym mieszkańcom omawianych miast, jak i osobom je odwiedzającym.

\section{Organizacja i ocena „Nocy Muzeów” w Lodzi}

Pierwsza „Noc Muzeów” w Łodzi została zorganizowana w 2005 r. Od początku za program imprezy i jej przebieg odpowiada Biuro Promocji Miasta, co wynika z faktu, że wydarzenie to, począwszy od pierwszej edycji, włączone zostało i odbywa się razem ze "Świętem Łodzi”. W organizacji przedsięwzięcia współuczestniczą przede wszystkim instytucje kultury, które dostarczają głównych atrakcji na ten specjalny czas oraz Redakcja "Gazety Wyborczej" odpowiedzialna za promocję wydarzenia (także relacje) i Miejskie Przedsiębiorstwo Komunikacyjne umożliwiające transport pomiędzy placówkami.

Obserwując programy dla kolejnych edycji „Nocy Muzeów” w Łodzi widać, że systematycznie wzrasta liczba instytucji zainteresowanych udziałem w wydarzeniu (z ośmiu w 2005 r. do 38 w 2012 r. - rys. 6) oraz ich zróżnicowanie (muzea, galerie, szkoły artystyczne, parafie wyznaniowe). Jak dotąd wśród współorganizatorów dominują muzea, choć ich udział w ogólnej liczbie instytucji systematycznie spada (w 2005 r. stanowiły one 100\%, w 2012 tylko ok. 58\% wszystkich instytucji) i w przyszłości tendencja ta będzie się zapewne pogłębiać, choćby ze względu na ograniczoną liczbę tych placówek w mieście (muzea wraz z oddziałami stanowią 23 obiekty). Analiza programów wskazuje, że nie wszystkie łódzkie muzea (i pozostałe instytucje) uczestniczą w imprezie każdego roku. Głównym powodem nieuczest- 
niczenia tych instytucji kultury $\mathrm{w}$ wydarzeniu są najczęściej ograniczenia finansowe, powierzchniowe, personalne lub względy bezpieczeństwa.

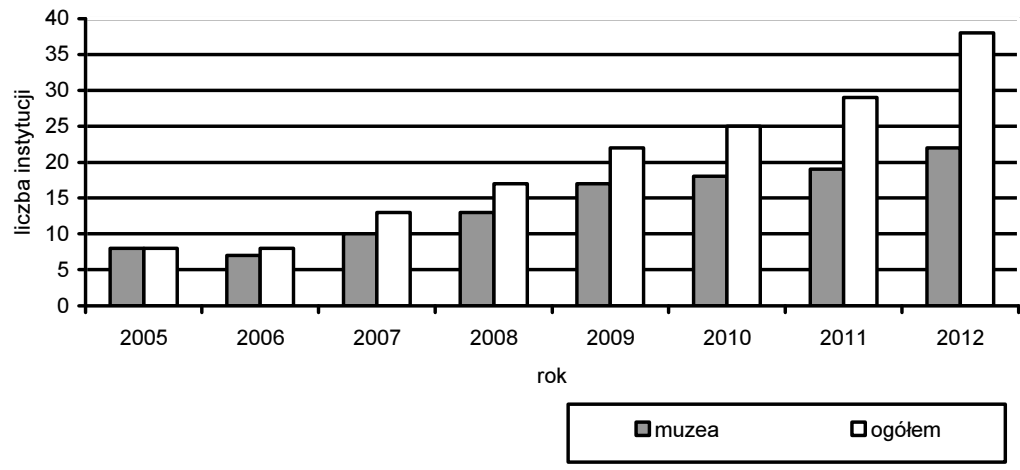

Rys. 6. Liczba instytucji w Łodzi uczestniczących w „Nocy Muzeów” w latach 2005-2012 Źródło: opracowanie własne na podstawie programów wydarzenia

Do stałych muzealnych uczestników akcji w Łodzi należą natomiast: Muzeum Sztuki, Muzeum Archeologiczne i Etnograficzne, Muzeum Tradycji Niepodległościowych, Muzeum Kinematografii, Muzeum Historii Miasta oraz Muzeum Włókiennictwa. Przeglądając plan Łodzi z zaznaczonymi wszystkimi instytucjami biorącymi udział w wydarzeniu (rys. 7) można stwierdzić, że większość placówek zlokalizowanych jest w centrum miasta, co niewątpliwie ułatwia odwiedzenie $w$ tym dniu więcej niż jednej instytucji. Skrajnie położone obiekty to dwa muzea - Muzeum Tradycji Niepodległościowych Oddział Martyrologii na Radogoszczu (północ miasta) i Centralne Muzeum Włókiennictwa (południe).

Krytyczna ocena programów łódzkiej „Nocy Muzeów” wskazuje, że w zakresie działalności ekspozycyjnej instytucje najczęściej prezentują swoje wystawy stałe lub czasowe przygotowywane niezależnie od tego wydarzenia, a wiele wystaw powielanych jest w następnych jego edycjach (np. w muzeach czy galeriach). Większa inwencja widoczna jest w pozostałych działalnościach, tzn. edukacyjnej, kulturalnej czy rozrywkowej, choć tylko niektóre placówki proponują dodatkowe atrakcje przygotowane specjalnie na ten dzień (tj. warsztaty, koncerty, pokazy). Niewątpliwie dużym zainteresowaniem odwiedzających cieszą się atrakcje organizowane poza murami budynków, na dziedzińcach muzealnych czy w przestrzeni publicznej (np. 
pokazy sztucznych ogni, koncerty, pokazy tańców, wystawy fotografii). Z punktu widzenia odwiedzającego wydaje się, że najciekawsze jest to, co nowe lub niemożliwe do zobaczenia na co dzień, dlatego też oprócz muzeów czy galerii popularnością cieszą się takie placówki, jak np. oddział Instytutu Pamięci Narodowej, Akademia Sztuk Pięknych, Filharmonia Łódzka czy Wyższa Szkoła Filmowa (przykłady dotyczą 2012 r.).

Chcąc dowiedzieć się więcej na temat „Nocy Muzeów” w Łodzi przeprowadzono badania ankietowe $\mathrm{z}$ uczestnikami tego wydarzenia. Badania takie odbyły się w maju 2009 r. podczas piątej edycji, a objęto nimi 220 osób w 22 instytucjach muzealnych (po 10 osób w każdej) biorących udział w muzealnej nocy. Poprzez zadawane pytania udało ustalić się, że wśród uczestników dominowały osoby młode (grupa 18-25 lat - ok. 40\%, 26-35 - blisko 25\%) i dobrze wykształcone (ok. $80 \%$ uczestniczących posiadało średnie i wyższe wykształcenie). Prawie $85 \%$ badanych stanowiły osoby z Łodzi, ale nie zauważono związku pomiędzy miejscem zamieszkania a odwiedzanym obiektem. Spośród ankietowanych pierwszy raz w wydarzeniu wzięło udział około $49 \%$ osób, dla pozostałych była to ponowna wizyta (ok. 51\%). Jak wynika z uzyskanych odpowiedzi, powodami uczestnictwa w „Nocy Muzeów" były przede wszystkim: chęć interesującego spędzenia czasu (ok. $29 \%$ ), odwiedzenie placówek muzealnych bezpłatnie (ok. 20\%), ciekawość (ok. 16\%) oraz odwiedzenie ulubionych muzeów (ok. 13\%). Większość osób zwiedzała instytucje w towarzystwie innych - znajomych (ok. 53\%) i rodziny (ok. 41\%). Pytani deklarowali chęć odwiedzenia m.in.: Muzeum Sztuki, Historii Miasta, Muzeum Kinematografii, Centralne Muzeum Włókiennictwa, a głównymi tego powodami były chęć poznania wystaw (ok. 33\%), tematyki (ok. 33\%), obiektu (ok. 10\%) oraz dodatkowych atrakcji (ok. 10\%). Pomimo krytycznych uwag (np. długie kolejki - ok. 28\%, krótki czas otwarcia placówek - około 11\%), badani ocenili wydarzenie dobrze (ok. 62\%) i bardzo dobrze (ok. 26\%), a jako główne jego atuty podali bezpłatne wejścia (ok. $34 \%$ ), zorganizowany dojazd (ok. 11\%), dogodne godziny otwarcia (ok. 8\%) (SKRYDALEWICZ 2010).

Kolejne edycje „Nocy Muzeów” w Łodzi pozwalają zaobserwować nie tylko ogólny wzrost popularności wydarzenia, wyrażający się zwiększeniem liczby obiektów oraz zróżnicowaniem instytucji, ale także większym zaangażowaniem w poszukiwaniu właściwej formuły i swojego miejsca $\mathrm{w}$ tej imprezie (np. nadawanie własnych nazw dla wydarzenia - „Biała Noc w Białej Fabryce" - Muzeum Włókiennictwa). Coraz bardziej powszechne staje się 


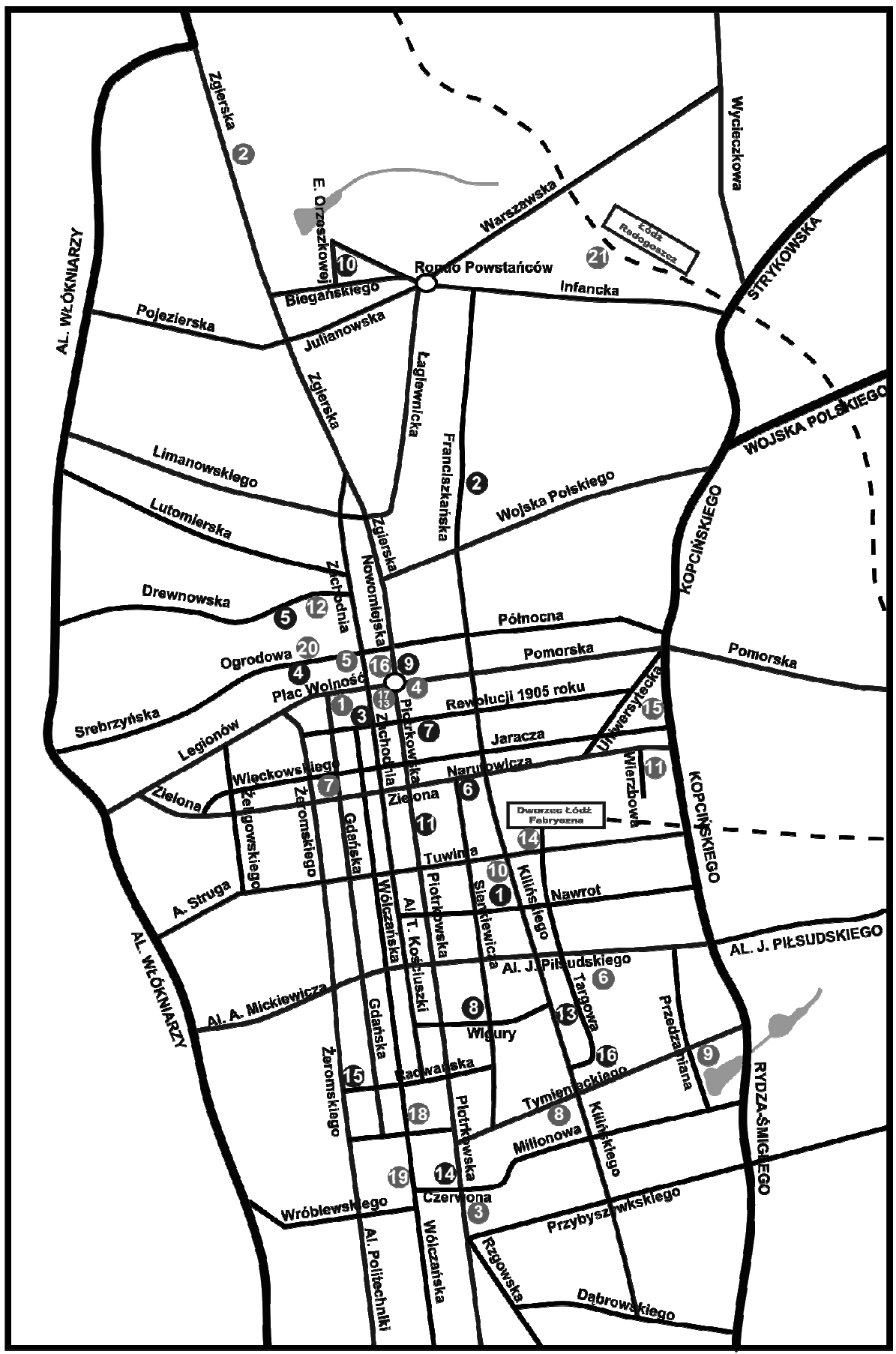


Muzea uczestniczące w „Nocy Muzeów” w 2012 r.

1. Muzeum Tradycji Niepodległościowych

2. Muzeum Tradycji Niepodległościowych - Oddział Martyrologii Radogoszcz

3. Centralne Muzeum Włókiennictwa

4. Muzeum Archeologiczno-Etnograficzne

5. Muzeum Historii Miasta Łodzi

6. Muzeum Kinematografii

7. Muzeum Sztuki - Gmach Główny

8. Muzeum Książki Artystycznej

9. Muzeum Sztuki - Pałac Herbsta

10. Muzeum Przyrodnicze UŁ

11. Muzeum Komunikacji Miejskiej

12. Muzeum Fabryki

13. Muzeum Historii Farmacji

14. Muzeum Bajki Se-ma-for

15. Muzeum Geologiczne Ut

16. Muzeum Kanału "Dętka"

17. Muzeum Historii Miasta - Oddział Kultur i Tradycji Wyznaniowych

18. Muzeum Oświaty Ziemi Łódzkiej

19. Muzeum Papieru i Druku

20. Muzeum Sztuki - ms2

21. Muzeum Tradycji Niepodległościowych - Oddział Stacja Radegast
Pozostałe instytucje kultury uczestniczące w „Nocy Muzeów” w 2012 r.

1. Ośrodek Propagandy Sztuki

2. Akademia Sztuk Pięknych

3. Akademicki Ośrodek Inicjatyw Artystycznych

4. Centrum Kultury RYBA

5. Centrum Nauki Experymentarium

6. Filharmonia Łódzka

7. Galeria Kredens

8. Galeria Manhattan

9. Galeria Multimedialna Centrum Dialogu

10. Instytut Pamięci Narodowej

11. Kino Polonia

12. Muzeum Rozproszone

13. Państwowa Wyższa Szkoła Filmowa

14. Parafia Ewangelicko-Augsburska św. Mateusza

15. Parafia Ewangelicko-Reformowana

16. Willa Grohmana

Rys. 7. Rozmieszczenie instytucji biorących udział w „Nocy Muzeów” w 2012 r.

Źródło: opracowanie własne na podstawie programów wydarzenia

też wprowadzanie wejściówek czy wcześniejszej rejestracji jako form limitowania ruchu, a tym samym zapewnienia większego komfortu odwiedzającym (szczególnie w przypadku warsztatów, wycieczek czy innych atrakcji specjalnych). Począwszy od 2010 r. wydarzeniu towarzyszy promocja łódzkich instytucji kultury biorących udział w akcji na portalu Noc-Muzeów.pl. Ciekawostką w 2011 r. było też wprowadzenie do oferty łódzkiej „Nocy Muzeów" tras wycieczek związanych z "zaginioną dzielnicą" Litzmannstadt Getto (dziedzictwo żydowskie), funkcjonujących pod wspólną nazwą „Muzeum Rozproszone" czy atrakcji wykraczającej poza miasto - przejazd pociagiem zorganizowany przez Fundację Kolei Wąskotorowej (wyjazd ze stacji Łódź Widzew do Rogowa, stamtąd przejażdżka kolejką wąskotorową na trasie Rogów - Jeżów, przejazd do Skierniewic i zwiedzanie zabytkowej parowozowni).

Łódzka „Noc Muzeów” jest jedną z kilkudziesięciu imprez kulturalnych organizowanych w ciągu roku w mieście. Wiele $\mathrm{z}$ nich, ze względu na cykliczny charakter, na stałe wpisało się w historię i współczesne oblicze 
miasta. Do najpopularniejszych wydarzeń kulturalnych należą m.in. Festiwal Czterech Kultur, Festiwal Kultury Chrześcijańskiej, Explorers Festival, Łódzkie Spotkania Baletowe, Łódź Biennale czy Jarmark Wojewódzki. „Noc Muzeów" jednak jako jedna z niewielu promuje instytucje kultury, w tym placówki muzealne, na taką skalę. Spośród licznych wydarzeń organizowanych w Łodzi "Noc Muzeów” ma podobny charakter do Festiwalu Nauki Techniki i Sztuki. Podobieństwo to przejawia się zarówno w instytucjach uczestniczących w wydarzeniu (szkoły wyższe, muzea, teatry), jak i w jego formule (instytucje są otwarte poza tradycyjnymi godzinami odwiedzających, proponują liczne atrakcje - wykłady, prelekcje, pokazy, wystawy itp.). Także łódzkie muzea mają swoje festiwale organizowane $\mathrm{z}$ dużym powodzeniem od wielu lat i kojarzone z konkretnym obiektem, np. Festiwal Muzyki Filmowej organizowany przez Muzeum Kinematografii czy Międzynarodowe Triennale Tkaniny organizowane przez Centralne Muzeum Włókiennictwa.

Obserwacja oferty łódzkich placówek na muzealną noc w kolejnych edycjach oraz opinie uczestniczących w wydarzeniu skłaniają do wskazania propozycji przyszłych działań dla potencjalnych uczestników (instytucji), w tym muzeów, aby było ono konkurencyjne i lepiej rozpoznawalne. $\mathrm{Na}$ pewno warto zadbać o to, aby „Noc Muzeów” wyłączyć ze Święta Łodzi i postarać się, by była ona samodzielnym wydarzeniem, świętem instytucji kultury ze wspólnym logo wydarzenia powielanym w kolejnych edycjach. Wykorzystując doświadczenia innych placówek należy bardziej zaangażować się w tworzenie oryginalnych programów na każdy rok, np. wprowadzając noce tematyczne, umożliwiające prezentację zbiorów i działań łączących się z konkretnym hasłem. Warto też umożliwić odwiedzającym bardziej aktywne uczestnictwo w wydarzeniu, a także wyjść w plener $\mathrm{z}$ atrakcjami, tak aby dać szansę uczestniczenia w imprezie większej liczbie osób. W przyszłości należy pomyśleć o stworzeniu samodzielnej komórki integrującej instytucje kultury i ich działania (nie tylko przy okazji wydarzenia) oraz zaplanować bliższą współpracę pomiędzy instytucjami położonymi w sąsiedztwie. Proponowane działania mają na celu oprócz uatrakcyjnienia "Nocy Muzeów” i przyciągnięcia nowych odbiorców (nieco starszych, spoza miasta, ...), dbanie o odpowiednio wysoki poziom imprezy. 


\section{5. „Noc Muzeów" jako wydarzenie}

„Noc Muzeów” to wydarzenie, które powinno przynosić korzyści zarówno placówkom kultury, jak i uczestnikom. Dla instytucji uczestnictwo w wydarzeniu to nobilitacja ze względu na udział w przedsięwzięciu o międzynarodowym znaczeniu i rozpoznawalnej marce, możliwość integracji wokół wspólnego celu - promocji kultury, miasta, obiektu, wpływanie na określone zachowania i postawy w zakresie kultury, a także możliwość kreowania pozytywnego wizerunku instytucji. W przypadku uczestników udział w „Nocy Muzeów" to okazja do poznawania obiektów, ich zbiorów i działalności, zbliżenie się do tzw. wysokiej kultury, interesująca alternatywa dla innych sposobów spędzania czasu wolnego.

Przedstawione korzyści wydają się być oczywiste, dlatego warto zastanowić się także nad ograniczeniami związanymi z tym wydarzeniem. Aby lepiej je wyeksponować, należy rozważyć różnice pomiędzy muzealną nocą a muzealnym dniem (tab. 3). Takie porównanie wydaje się być uzasadnione, bowiem "Noc Muzeów” jest w ciągu roku tylko raz, a dni jest ponad 300 (wyłączając dni wolne, najczęściej poniedziałki). Oczywiście bywają też bardziej niezwykłe dni dla placówek muzealnych, tj. np. "Dzień Otwarty”, „Dzień Otwartych Drzwi” czy wręcz weekend muzealny - „Muzeobranie”, „Tydzień Muzeów”, ale jest ich mimo wszystko niewiele (rys. 8).

Tabela 3. Różnice pomiędzy muzealnym dniem a „Nocą Muzeów”

\begin{tabular}{|c|c|}
\hline Dzień muzealny & Noc muzealna \\
\hline $\begin{array}{c}(-)^{*} \\
\text { Codzienność, powszedniość, zwyczajność } \\
\text { Ustalone godziny otwarcia } \\
\text { Stałe propozycje } \\
\text { Płatny wstęp } \\
\text { Dojazd we własnym zakresie }\end{array}$ & $\begin{array}{c}(+) \\
\text { Wyjątkowość, specyficzna atmosfera } \\
\text { Nietypowe godziny otwarcia } \\
\text { Liczne nowe atrakcje } \\
\text { Darmowe wejścia } \\
\text { Zorganizowany, bezpłatny dojazd }\end{array}$ \\
\hline $\begin{array}{c}(+) \\
\text { Większy spokój w organizacji pracy } \\
\text { Wąskie grono odbiorców } \\
\text { Wygoda zwiedzania } \\
\text { Swoboda w dysponowaniu czasem } \\
\text { Możliwość indywidualnego przeżywania }\end{array}$ & $\begin{array}{c}(-) \\
\text { Duży wysiłek organizacyjny } \\
\text { Tłumy zwiedzających } \\
\text { Dyskomfort oglądania } \\
\text { Duża presja czasu } \\
\text { Zaliczanie atrakcji, powierzchowne oglądanie }\end{array}$ \\
\hline
\end{tabular}

* (+) korzyści $\quad(-)$ ograniczenia.

Źródło: opracowanie własne. 
Sporządzone zestawienie (tab. 3) pokazuje, że „Noc Muzeów” ma w sobie wiele cech święta - dla organizatorów jest to oczywiście wiele pracy, ale dla gości stanowi coś niezwykłego, wyjątkowego, na co składają się choćby liczne atrakcje. Z kolei muzealny dzień jest przewidywalny, zwykły, pozbawiony tej specyficznej atmosfery i jakby z góry uznany za mało ciekawy, choć większa swoboda oraz komfort oglądania i przeżywania (mniej odwiedzających, mniejsza presja czasu) są niewątpliwie jego dużymi atutami. Teoretycznie w noc muzealną można zobaczyć i doświadczyć więcej, ale towarzyszy temu większy pośpiech, powierzchowność i „zaliczanie” atrakcji. Biorąc pod uwagę zadania, jakie realizują muzea wydaje się, że muzealny dzień koncentruje się bardziej na ekspozycji i edukacji, a noc na wydarzeniu i rozrywce, tym samym oczywiste jest, że do uczestniczenia w kulturze potrzebne są i dzień codzienny i muzealna noc, które powinny uzupełniać się pod względem oferty.
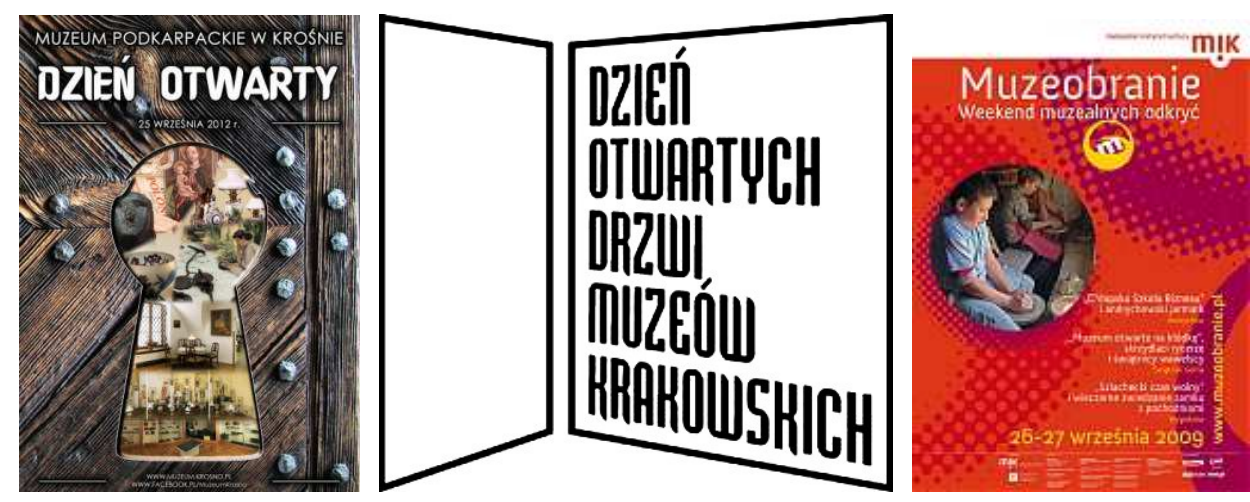

Rys. 8. Plakaty reklamowe zachęcające do odwiedzenia muzeów w konkretne dni roku Źródło: www.krosno24.pl,www.albumpolski.pl, www.archiwum.andrychow.eu

Biorąc pod uwagę fakt, że według badań przeprowadzonych w maju 2012 r. ${ }^{1}, 86 \%$ badanych pozytywnie ocenia akcję, $4 \%$ - negatywnie, pozostali nie mają zdania, a w opinii $83 \%$ respondentów wydarzenie powoduje większe zainteresowanie muzeami, warto spojrzeć na „Noc Muzeów” także w kontekście produktu turystycznego. Przyjmując, że produktem jest wszystko to, co można zaoferować nabywcom do konsumpcji, zbiór korzyści

\footnotetext{
${ }^{1}$ Badania przeprowadzone zostały przez ARC Rynek i Opinia w dniach 15-16 maja 2012 r. na próbie 532 osób (www.arc.com.pl).
} 
i całość doświadczeń z nim związanych (KACZMAREK, STASIAK, WŁODARCZYK 2010) należy uznać, że muzealna noc jest produktem z kategorii „wydarzenie", który składa się z wielu elementów składowych (wystawy, wykłady, pokazy), spójnych tematycznie, odbywającym się w określonym czasie i miejscu w przestrzeni. Patrząc na wydarzenie z perspektywy kilku lat należy stwierdzić, że funkcjonuje ono w świadomości odbiorców i ma swoją markę, a jego organizację umożliwia z jednej strony potencjał kulturalny (muzealny), a z drugiej zapotrzebowanie na kulturę. Pewnego rodzaju ciekawostką jest to, że produkt ten jako całość (w skali kraju) nie ma wyraźnego jednego organizatora, a poszczególne województwa, miasta czy obiekty włączają się w wydarzenie dobrowolnie, na zasadzie inicjatywy oddolnej. Elementem integrującym i spajającym poszczególne miasta w całość są natomiast portal Noc-Muzeów.pl oraz lokalne media. Warto podkreślić też, że produkt ten obejmuje coraz większą przestrzeń polskich miast, a tym samym naszego kraju, stając się powszechnie dostępnym, a ze względu na udział wielu uczestników masowym wydarzeniem o wspólnotowym charakterze, w którym kultura jest niewątpliwie siłą spajającą.

\section{Zakończenie}

Obok funkcji wystawienniczej i edukacyjnej coraz częściej muzea podejmują się trudu organizacji wydarzeń kulturalnych. Kilka kolejnych „Nocy Muzeów" w Polsce skłania do tego, aby spojrzeć na to wydarzenie w kontekście celów, jakie ma ono realizować. Co prawda nie ma precyzyjnych danych liczbowych świadczących o rozmiarach zjawiska, ale tłumy osób przemieszczających się w tę noc po miastach i oczekujących na wejście do poszczególnych obiektów potwierdzają że jest to wydarzenie popularne, które rzeczywiście przyciąga, głównie młodych, ale nie tylko, popularyzując jednocześnie wiedzę o obiektach i promując je. Trudno jednoznacznie stwierdzić, czy uczestnictwo w "Nocy Muzeów” wyrabia nawyk uczestniczenia w szeroko rozumianej kulturze, ale na pewno do niej zbliża. Ewentualna chęć uczestniczenia w kulturze zależy przecież nie tylko od uczestników, ale od samych instytucji, od tego, czy są one w stanie stworzyć ciekawą ofertę na cały rok, którą przyciągną zarówno tych, którzy brali już udział w tej akcji, jak i nowych odbiorców. Coraz więcej miast i instytucji jako uczestników 
oraz większa ich różnorodność optymistycznie nastawia co do przyszłości tego wydarzenia, choć jest też obawa, czy to ciągle jest „Noc Muzeów” czy może już „Noc Kultury”, czy muzea nie schodzą na drugi plan, zdominowane przez inne instytucje.

Jakkolwiek nie analizować tego wydarzenia „Noc Muzeów” należy uznać za zjawisko społeczne, w którym - jak pokazują badania - uczestniczą osoby nieprzypadkowe, ale wykształcone, świadome tego wydarzenia oraz tego, co chcą zobaczyć, zmotywowane różnymi powodami, które $\mathrm{w}$ towarzystwie innych, najczęściej rodziny i znajomych, zarówno pierwszy raz (jest zainteresowanie), jak i ponownie (wciąż jest coś do zobaczenia), przybywają zazwyczaj z najbliższego otoczenia (lokalny zasięg), oceniając pozytywnie wydarzenie i traktując je jako muzealną przygodę.

\section{BIBLIOGRAFIA}

KaczMAReK J., StASIAK A., WŁODARczYK B., 2010, Produkt turystyczny, PWE, Warszawa.

KOWALCZYK W., 2010, Celebrować, zabawiać czy edukować? Po co społeczeństwu sq dziś publiczne muzea?, „Muzealnictwo” 51, s. 55-62.

KRAKOWIAK B., 2007, Rozmieszczenie muzeów w Polsce, „Turyzm” 1-2/17, s. 173-182.

KUREK W., 2007, Turystyka, Wydawnictwo Naukowe PWN, Warszawa.

RoKosz K., GŁOWACKI P., 2008, „Noc Muzeów” - zjawisko kulturowe i społeczne ostatnich lat, „Muzealnictwo" 49, s. 286-293, Krajowy Ośrodek Badań i Dokumentacji Zabytków, Warszawa.

SKRYDALEWICZ E., 2010, Noc Muzeów jako wydarzenie kulturalne Łodzi, maszynopis pracy licencjackiej napisanej w Instytucie Geografii Miast i Turyzmu Uniwersytetu Łódzkiego, Łódź.

SZElĄG M., 2008, Noc Muzeów w opiniach publiczności, „Muzealnictwo” 49, s. 295-303, Krajowy Ośrodek Badań i Dokumentacji Zabytków, Warszawa.

Ustawa z 21 listopada 1996 r. o muzeach, Dz.U., 20 stycznia 1997 r., nr 5, poz. 24.

www.Noc-Muzeów.pl.

www.albumpolski.pl.

www.arc.com.pl.

www.archiwum.andrychow.eu.

www. daringtodo.com.

www.konrad-auwaerte r.de.

www.krosno24.pl.

www.nuitdesmusees.culture.fr.

www.lublin.dlastudenta.pl.

www.poznan.planeta.fm.

www.szlakimalopolski.mik.krakow.pl. 